\title{
HMB45 Positive Cells Present
}

National Cancer Institute

\section{Source}

National Cancer Institute. HMB45 Positive Cells Present. NCI Thesaurus. Code C150425.

An immunohistochemical finding that the monoclonal antibody HMB-45 binds to a the cells in a biosample. 